\title{
Shifting Cultivation of Arfak Farmer in Somi and Indisey Villages
}

\author{
${ }^{1}$ TRIMAN TAPI, ${ }^{2}$ GANJAR KURNIA, ${ }^{3}$ IWAN SETIAWAN, ${ }^{4}$ AGUS SUMULE \\ ${ }^{1}$ The development of Agriculture Polytechnic Manokwari, West Papua \\ 2,3Agriculture department of Padjadjaran University \\ ${ }^{4}$ Agriculture department of Papua University, Manokwari \\ correspondence: 13manstppmkw@gmail.com
}

\begin{abstract}
Shifting cultivation of Arfak farmer is a traditional planting which they inherited from their ancestor. This research aims to explain the environmental condition of shifting cultivation in Indisey and Somi villages and the barriers in socio-economy, social capital, and human capital. This research applies a cross-sectional study which is taken in a short period of time and done step by step to get certain points that lead to a clear conclusion. The results of the study show that shifting cultivation condition in Indisey and Somi villages have the fertility soil signed by the existing of trees called Bembuk and Ciskua. The farmworkers are their own family members and there are job divisions between men and women. There is also a traditional policy called Igya ser hanjob to manage the social life and natural resources of Arfak ethnic. The result of study also shows that the socioeconomic condition of Arfak's community is started to improve. They are generous people who would love to give after they fulfilled their own needs. They open to new things and would like to learn from others. If there is conflict, it is due to the culture shock of local people when they have to follow the government program namely resettlement and the land demand of the palm oil expansion.
\end{abstract}

Keywords: shifting cultivation, arfak, socio-economy

\section{Introduction}

According to the perspective of Papua indigenous, nature is God and spirits as the unity that covers the human life to manifest a monism preaching which has positive purposes. Humans are part of nature; if human destroys the forest, they destroy themselves. Papua indigenous identifies nature as their parent; they call it 'MAMA' (mother). In their community, soil is an important thing. The name 'MAMA' or mother given to nature and forest shows the close relationship of indigenous people with the forest that gives them protection and fulfill their needs.

The perished of forest and marsh will significantly disrupt the local prosperity and quality because people can't get staple their foods such as sago (carbohydrates), meats from hunting (protein), and several forest industries (rattan, log and nibong/feather palm).

Cultivation activity means planting trees/plants on an empty land with one or two times of harvesting. The time period of the land fallow is uncertain. The land is usually left fallow (fallow period/break period) for three and ten years. They plant the sweet potatoes as the staple food, while the Arfak local in Warmare district opens the rice paddy. The mixed farming pattern is conducted between food crops and vegetables. Apomfires and Sapulete say that Arfak local has a system to grow plants. They choose a certain area of forest as their ground/base to be burned, plowed, and tilled (Hujairin, Ismadi, \& Kustana, 2017). Shifting cultivation is a time-tested system of agriculture activity, frequently done indigenously and is strongly based on traditional knowledge. It is assumed to be an appropriate and sustainable land use practice

Received: 2020-03-28, Revised: 2020-05-05, Accepted: 2020-06-03. 
in diverse socio-economic (R.S. Tripathi and S.K. Barik, 2003). Shifting cultivation is a form of land use by poor communities who have limited resources with a rotation of cultivation and fallow in the same unit of land (Kafle Gandhiv, 2011). Food and Agriculture Organization of the United Nations mentions that the land is used for rotational farming and swidden farming or slash-and-burn. FAO states three common features of land use, namely cutting and burning in the short duration, a comparatively long duration of burn or forest fallow, and the shifting of fields (Cavenett, 2013). The shifting cultivation system is rare due to its compatibility with the socio-physical environment characterized by a sparse population, the form of community land tenure system, undulating topography, and insufficient resources (Singh, Purohit, \& Bhaduri, 2016).

Recently, the custom forest as a shifting cultivation area has been switched to palm oil area. It makes the indigenous and urban local undergo a jump of civilization. This event occurs unnaturally and it may be called culture shock. Culture shock happens when local culture is forced to change into capitalism without passing the natural way (Howay, 2016). The impact is alienation and marginalization, physically and psychologically.

Shifting cultivation alternation occurs due to the land demand which aims for the palm oil expansion that triggers the high rates of land conversion and gives several impacts to the indigenous. The palm oil development has caused deforestation which give impacts on water pollution, erosion, and air pollution. Other disadvantages are the indigenous people as the landowner undergo the right limitation to use the area, the scarcity of area, and the increase in land price and an area conflict (Obidzinski, Andriani, Komarudin, \& Andrianto, 2012). The rise is almost treble, which was 171, 900 hectares per year in the period of 2009 to 2013. In the next period of 2013 to 2017, the deforestation has risen by 189,3 hectares per year. By the year 2030, the needs will be about 125 million to 416 million hectares area, yet around 30 to 80 million hectares of agriculture area run into degradation and reduce productivity. By around 29, 8 million hectares areas displace and only 7,9 million hectares have the potential for agriculture intensification. Forest Watch Indonesia reported the increase of deforestation was about 60,3 thousand hectares per year (Papua \& Islands, n.d.). The loss of forest function caused by the palm oil expansion might initiate an extra vulnerability to the indigenous. Greenpeace claimed that about 3000 hectares are in critical condition every year and the palm oil plantation is one of the triggers (Watch, 2013).

Palm oil plantation is one of the government programs that have a purpose to lift the country's economy which includes the utilization of certain areas in Indonesia. East Indonesia becomes the most target area. The market demand for palm oil production is very high that responded by the plan of opening a new plantation area. On the other hand, local thinks the plan as a threat and emerges a social conflict. Hence, the government map out the communal right based on the special autonomy regulation number 21 of 2001 and has an obligation to guarantee the achievement of customary rights.

Furthermore, several opposite opinions mention that shifting cultivation is the cause of deforestation and unsustainable land. Deforestation also occurs due to pressures, such as demographic pressure that force people to get lands while the system of slashand-burn has the prolonged-time period which threat the regeneration of forest and can't keep the soil fertility(Ickowitz, 2004). Ickowitz, Bass, and Elaine write that the most popular perspective amongst those who set policy is that shifting cultivation is a destructive and unsustainable use of forest. It caused forest loss, degradation, and soil erosion (Bass Stephen and Elanie Morrison, 1994). Yet, the contradicted about shifting cultivation is several statements saying that shifting cultivation is actually an effective way and able to maintain the forest sustainability for the fallow time (Talaohu, 2013). Sunderlin (in Talaohu, 2013) reveals that the different perceptions of shifting cultivation are caused by inaccurate definition which refers to many types of activity namely long fallow shifting cultivation, short fallow shifting cultivation, and forest pioneer.

Subsequently, one program called resettlement revealed and give a bad effect for the socio-economy condition of indigenous people. Generally, Papua has a different social culture compared to other Indonesia ethnicities. This case has social impacts. Several local transmigrants have carried out the program while the others were not. Hence, for the local, it takes understanding and quite some time to be able to join the government program. It also needs a great 
patient for them to well integrate with others. The program can't just get in without socialization and adaptation. The benefit of transmigration program in Papua is not yet enjoyed by local people who spare their area for the transmigration program(Yuminarti, 2017). Yuminarti further reveals that the problem above arises due to the transfer of knowledge (mainly about agriculture) which is too late from transmigration farmers to local people. Hence, local people who still work as a hunter and herbal maker need a longer time to change their habits. In this program, the government also aims to improve the human resources in Somi and Indisey villages. It has a purpose to create a reciprocal relationship that gives benefits. It has been done continually and it looks like there is an increase in palm oil production but creates an unbalance condition since it does not suit Arfak farmer culture. This situation reflects the government failures indicated by the stagnant in the elements of socio-economy of migration, minorities, population, health, occupation, and education (Sodarak, 1999). Palm oil expansion and resettlement program have brought difficulties to a local farmer to cultivate using the rotation planting system because there is no forest left which functions to fertile the soil as the major component to continue their livelihood activity.

The research locations are in Indisey and Somi villages, two districts in Manokwari regency, West Papua. The indigenous people who live in these areas are generally the ethnic group of Arfak that consist of Hatam, Moile, and Sougb. These ethnicities are hanging their life on the forest. They work as farmers, hunters, and herbal makers. Indisey and Somi villages are also occupied by the indigenous, urban people, and transmigrants as the result of the resettlement program.

There are several theories that support this research: first, Sodarak (1999) who writes about the environmental of shifting cultivation which are soil, labour, gender, policies, and the socio-economy. Second is Apomfires and Sapulete (in Hujairin et al., 2017) who state that Arfak ethnic has and did their own system to grow plants. They choose a certain area of forest as a ground to be plowed and burned. Third is Hastanti \& Yeny (2009) who argue that the Arfak local is already have rule or policies called igya ser hanjob (in Hatam/Moule) or mastagow hanjob (in Sougb). If those theories are compared, then an asymmetrical condition can be identified. The increase of the palm oil plantation in Papua forest showed a big revolution that impacted the land and resources and directly affected the landscape change. Meanwhile, the fourth theory is referred to by Obidzinski et al., (2012) as the problem. He mentioned that the palm oil development had caused deforestation which gave external impacts, such as water pollution, erosion, and air pollution. The fifth is Yuminarti (2017) saying local people have not benefited anything from sparing their area for the transmigration program; they also late to have work of culture and proper education.

This research aims to describe the environmental condition of shifting cultivation in Indisey and Somi villages which include soil, labour, gender, policies the socio-economy condition, social capital, and human capital barrier (Sodarak, 1999), and the conflicts.

\section{Research Methodology}

This research is conducted in Somi village (Prafi district) and Indisey village (Prafi district) in Manokwari regency, West Papua (figure 1). Both villages are located at Southwest Manokwari. The villages can be accessed by using ground transportation which took about one hour and a half from Manokwari.

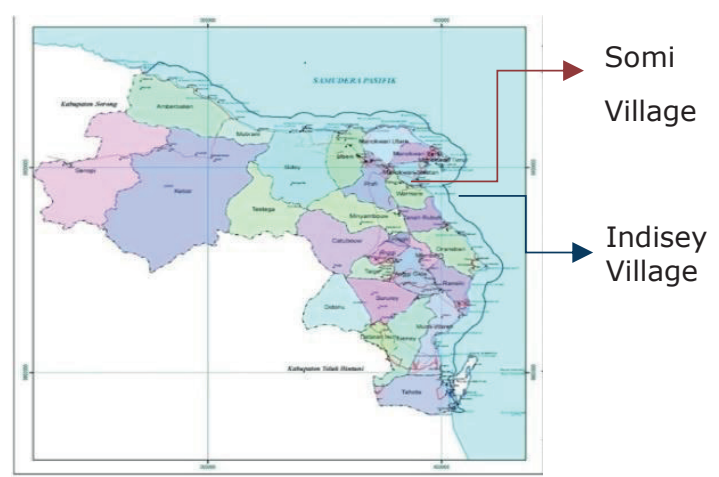

Figure 1. The map of the villages

This research applies a descriptive qualitative method with a case study approach. Bungin explained that descriptive qualitative research with a case study can be seen in cross-sectional which referred to retrospective feature (the research is done by using an established data such as previous documents) (Wijaya, 2018)

The primary data is collected from the correspondence and observation results, while the secondary data is in the form of the government agencies report and the institutions of non-governmental organizations 
as well as several references, either it is publicized or not. Correspondences were conducted with twenty-five houses of a family in Somi and Indisey. The family head or the family member who joined the program of Core Estate and Smallholder of Palm Oil were categorized as plasma farmers. This research chose ten respondents from Somi village and fifteen from Indisey village. For the primary data, snowball and purposive sampling were applied in this research (Sugiyono, 2016); (Bungin in Wijaya, 2018).

The data analysis was the combination of literature review, map, and the result of interviews with the key informants and the discussion with the stakeholder. Several stages of the qualitative analysis had been applied were: (1) Collecting the data relating to farming practice of Arfak ethnic that had settled as the palm oil farmer (2) Organizing the data (3) Verification and reducing the data and (4) Drawing a conclusion

\section{Results and Discussion}

The shifting cultivation in Indisey and Somi Villages is based on the same rule: carrying out the shifting cultivation by their ancestor's way. In this case, the discussion is about the soil, labour, gender, policies, and conflicts.

\section{The shifting cultivation in Indisey and Somi villages}

\section{Soil}

The soil selected for agriculture is based on the ground topography, the ground color, and the kinds of the tree/ plant. Topographically, Arfak local has the flat ground. It causes the simple technique of agriculture is relatively easy to be implemented since the soil color was dark. Arfak locals choose dark or red soil. In addition, the soil is also selected by observing two trees grow in the area, namely Bembuk and Ciskua. Arfak local believes if those trees are grown in an area, that area will definitely have fertile soil.

\section{Labour}

The opening new area should meet the farmer's needs (Yuminarti, Darwanto, Jamhari, \& Subejo, 2018). Generally, there is no exact measurement for the area being opened. Yet, it is overviewed through the family members who consume the plant and the closeness of the farming area with their house.

Women and men involve themselves in cultivation activities. The productive age is thirty-three. The minimal age is about twenty years old and the maximal is fifty-four. According to Katchova (Wescott, 2017), the productive age is believed to be able to carry out a trend and adopt the technology and new matter conducive to gain support.

The number of family members are farming capital. The Arfak local has roughly six people. The dependent household member is encouraged to be better in production and take the learning process (Aribawa in SURTANTIN, SUTJIPTA, \& PARINING, 2018)

\section{The Seasons of Shifting Cultivation}

By the rainfall, the Arfak divides a year into three seasons: brief growing season with brief rainfall from March to April (about seven days in a month), moderate growing season with moderate rainfall from May to August (about fifteen to seventeen days in a month), and large growing season with the highest rainfall from September to January (for twenty-three days in a month). The month estimated is uncertain because of the weather and the rainy seasons every year. The appropriate seasons to open the area of cultivation are the dry season for area opened by slashing and burning activities and the rainy season for planting while the harvest season is expected to occur in the dry season.

They estimate the seasons based on sun rotation. Arfak local also signs the coming of the planting season by the nature sign that is the sound of cricket which indicates the dry season will come. It signs the time to open the new area of planting. Spinach, corn, peanut, sweet taro, cassava, squash, and cucumber are the plants that planted. The cultivated area of Arfak local is inside the village of Warmare district, located on the hillsides around the villages (see figure 3 ). The cultivation pattern used is the mixed cropping pattern. The plants are grouped based on their type since the time of planting and harvesting of each plant is different. Commonly, after the planting, the plants are not given the preserving and the fertilizing. The seed derives from harvest time or bought from the agriculture market in the city. 


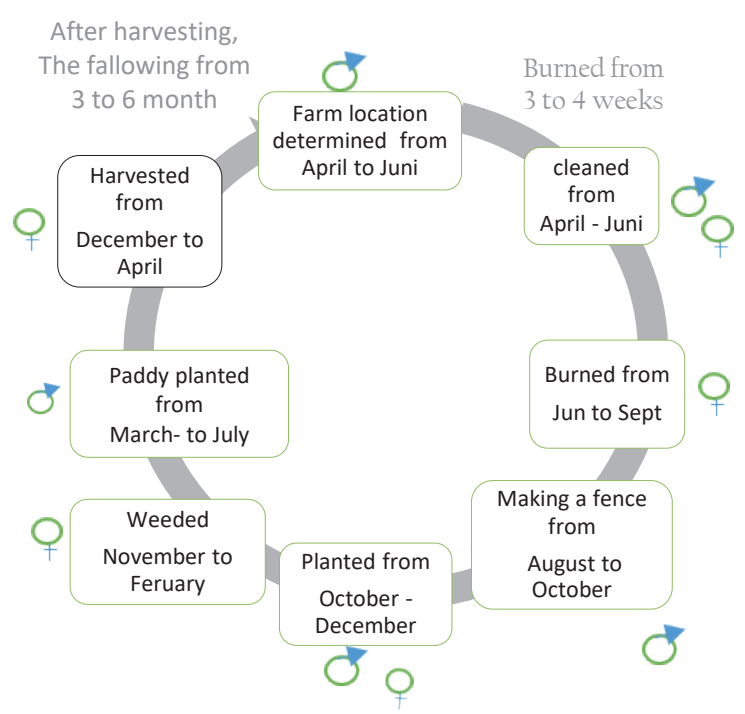

Figure 2

The Arfak farming cycle is family's job

\section{Gender: Woman and Men activities}

The farm cleaning is done by elementary family. Yet, if the farm area is big enough then the extended family or relatives will participate. The job division is suited to gender where hard work is done by men, such as cutting down the tree, making a fence, digging the land, and doing the hoe. Whereas, simple jobs that need patience and neatness are handled by women, such as slashing, planting, fertilizing, harvesting and selling (See figure 2 The Arfak farming cycle is family's job).

\section{Policies in traditional Cultivation}

A farm has been settled, yet the planting rotation still has the short fallow cycle for three to nine months. The space for the first area to the second area is not too far because the practice is done around the wasteland of the palm oil plantation. The ground average is about three hundred meters square and the Arfak local has more than one area for the planting but only one location is cultivated. Each farm is processed for two years after it rests (fallow time). The planting rotation is fully counted at the time of planting aiming at increasing the productivity of area. It is done by examining the soil types and fertilizer rate. On the other hand, when conducting agriculture practice or others, Arfak local must obey their belief and tradition. The concept of igya ser hanjob is the local's life philosophy which is to keep the natural resource management traditionally and to manage the social issues among them. Everything has limits and every person is required to keep their limits useful to their life. Humans and nature are the united cosmos. Igya ser hanjob for the Arfak local is an instrument that connects them to the cosmos directly. If the value is ignored, then Arfak local that has abounded will be isolated from the cosmos and the indigenous people.

The farming area in the research location is the food crop area depended on the land management and labour availability. The farming activities are dominated by women. In the area measured, the size may vary from 0.02 to 0.06 hectares, but the original area for food crop around the palm oil area is about 0.03 hectares. This is in contrary with the place where the local people do the shifting cultivation. Each of the head of family opens about 0.05 to 0.11 hectares. It is for the area of shifting cultivation that is not big enough and the farmer has a chance to open a wider area if as it contradicts to the farming settled. The family area of Arfak ethnics is communal and each family has a right and a responsibility as required by the customary elders based on the clan. Most parts of the farm that become the right of a family was used jointly by the whole families who have similar family names and therefore, a family has more than one area.

In the cultivation activities, the families, clan, and the whole village in Arfak ethnic are fully bounded by the right of the area. A conflict may happen if there are people who broke the area over. The chief of clan as the holder of communal rights has given a rule that every head of the family has to mark their area. The edge area is marked by a river/a creek, a tree, a certain plant, or a fence. In a region, it is necessary to have coordination for the land being used (Salosa et al., 2015) in order to minimize the conflict.

\section{Socio economy situation}

Living with a family name in their custom area is their characteristic that stands out in the kinship. The social situation in every community is built properly because it is part of the lifestyle of the community. The Arfak build a love commitment as their social system. In their life community, if they receive more in the context of wealth, they would not restrict their giving to other clans on meats or money only, but also their participation and responsibility to each other. The aids can be in the form of paying the fine 
if a clan is convicted of criminal action, the dowry payment traditionally, the violation of social norms that paid traditionally. Participation is a form of local lifestyle of the community that creates a generous attitude to each other. They realize that every person has similar potential. In fact, it inhibits the development of farming and causing their income from every economy activities can't be converted into venture capital. This fact shows that the social capital that supposed to support the increase of economic capacity acts oppositely, and the intensity of kinship ties in the community impacts the development of venture capital. Even though, they have intense kinship ties as the social capital. Data reveals that kinship starts the shifting in the life cycle of Arfak local. The downturn of communal features in the farm handling appeared since the local shifts to the palm oil that has more centralistic management.

\section{Human capital barrier}

Local farmers in the research location have limited knowledge and insight that implicate on the getting solution for the problems or making a better alternative solution to solve their life barriers. They have two simple perspectives: having enough food and they don't need to worry about life. That statement explains their limited thought until they need suggestions from others. The farmers' statements invite us to keep searching the solution for them regarding their fetter's situation due to their limited insight and their natural property that are in the hand of the stakeholder. The statement is also a challenge for stakeholders to find the right solution for all people (Papua and NonPapua) who live in the area who live naturally by their knowledge and skill to handle the agriculture area and other jobs. The stakeholders (the office of human resources agriculture) should play their roles to assist and empower the community, mainly refers to the counseling and information provision. It will open the insight of the farmers to do a construction job. The existence of the field immersion program in the research location has not received serious attention from the local government. Yet, the need of Arfak farmer is coaching and assistance to cope with their limited insight and natural resources in the area of the communal right. Arfak farmers have their own rule in using the forest. They are not only live for and from the forest, but the forest also draws their life perspective closely. Local farmers have a low level of education. According to the primary data, their formal education was about a quarter of six years. It means most of the farmers had only attended elementary school. The low level of farmer education affected the efficiency of the land used as the production factor and the capability to apply the modern techniques (Das \& Soo, 2012). In addition to policy planning and the implementation without local participation, the low level of education was also a factor that influences the farmers to continue shifting cultivation (Rahman, Rahman, \& Sunderland, 2012).

\section{Conflicts}

Farmers in Indisey and Somi Villages involved themself directly as cultivators in their subsistence land and as a plasma farmer in palm oil plantation who listed in the resettlement program.

Farmers' experience becomes incredibly important in farming practice. Farmers who have a lot of experience tend to have several skills in farming compared to those who have no experience. In other words, experience in farming gives an impact on farming quality. On average, farmers have 15 years of experience in farming because they have been working as plasma farmers since 2003 . The farming experience is highly effective in the first step of technology adoption (Ainembabazi \& Mugisha, 2014).

Arfak who lives in Warmare and Prafi districts are local people from Hatam ethnic. Commonly, they are the original ethnic of Arfak who live in mountain area that originally comes from the old Hink village which has been having the resettlement program. The resettlement is the government program to improve the standard of life and the preservation of forest as the conservation and the wildlife areas. After the resettlement program, Hatam ethnic has lost their access for using the traditional area. Among the local traditional law related to the land inhabited, there is the law on religion and magic (Malak Stephanus in Deda \& Mofu, 2014). No wonder if the Arfak called the forest diyebeidinieknye which means land or a forest that supports their needs. According to the local, the forest has religious meaning, can't be touched, and has time dimensions (past, present, future). Soil and forest contain life elements namely social, culture, religion, economy, and politics. Soil and forest are also places where they put 
their whole life for as well as a binder to the other Hatam generation. The binding between the forest and the local people is indicated by the forest being used as the source of food through the shifting cultivation. It is applied to help farmers who have limited knowledge about cultivation technology. Farmers try to search and handle the cultivated area that looks fertile to get a high level of production out of their agriculture system. The development of government administration and the palm oil expansion in Indisey and Somi villages undergo a limited area so that farmers are applying the cultivation slowly in a settled way. The entry of religion and the village system simultaneously influences the locals about their living essence and their life degree to natural dependency. Rationally, their living standard changed which refers to the farming pattern that impacts their economy.

By the entering of oil plantation, local people get their income in cash and they don't have to depend their lives on local farming production. In this context, maximally, farmer damages their farm based on their rational and count the item value that will be switched (Mosher in Ali, Yunus, Salman, \& Demmallino, 2018). An occupational safety concept is a choice when farmers have to take a risk, which also called rational choice (Scott in Ali, Yunus, \& Salman, 2018). The existence of partial modernization transformation in agricultural practice is economically oriented and has encouraged the change of Arfak social system primarily; it refers to the alteration in their institutional society.

The entry of new culture elements give an effect to the social system and traditional order of Arfak, especially in the leadership aspect which holistically impacts on the other traditional orders. Customs institution is behavior system that formed through the community activities. Social institution consists of the customs, the behaviors, and the cultural elements that assumed by the Arfak as a shifting process. The type of Arfak social institution is categorized in the crescive institution (the primary custom institutions). This is the institution evolutionarily derived from local custom which shifted by the new institutions that enter rightly and structurally. Andigipoy (the highest position in the village) was the first reality of local system; then it changed where the Andigipoy's function is handled by the village administration. A requirement to be a leader is being capable of fulfilling the community's need which is manifested through the leadership of the village head as the extension of government. The result is that the role of the head village is stronger. Moreover, the variation of development programs carried out by the village administration has directly given an impact for the community. The village administration of Arfak social system is recognized by the community and their obedience for every decision are the form of participation to follow the program and the aid. The nomadic Arfak farmers are willing to involve in palm oil management. The holders of the right communal openly welcome the company officials and agree on deforestation to be switched into the palm oil plantation. This condition makes the Arfak local, mainly the marginal farmers, loss their access to the traditional area and they forced to change to the monoculture practice. Social relation is not exclusive but it opens to the external effect. The global has also isolated the culture of Arfak cultivation as the life source. The social structure of Arfak I bounds a view that soil, forest, and water are the properties of indigenous that managed by their leader based on the hereditary tradition. The ethnics or family names that first time came and lived in an area belong to the whole area that had explored in their own area. The interview result reveals that the holder of the communal right came from Wonggor and Ullo family names. They have the right upon the land and whole natural resources while the other ethnic or family names (the resettlement) in the urban local who comes from the Hink lama village. The ownership pattern and the share of natural resources are classified into three patterns: getting them as a heritage, shifting to other family name area, and expanding the new area. The inheritance and governance area are founded on the family tree and the generation. The communal right and the governance of the resources are mandated by the ancestor for the firstborn of a family. The inheritance pattern is held by the communal principal in the ownership and the governance based on their descent. The social structure above gives an impact on the forest area management as the farming area of Arfak local. To explore the forest to make it into a farm, the company officials should get a license from the right communal holders to prevent conflict and a customary fine.

This research finds that the farm area only exists around the palm oil plantation. This circumstance is too different compared to the situation when they were still in Hink 
lama village. Social structure shows that Arfak ethnics highly uphold the customary law. To minimize conflict with the holder of the communal right, since their status is the urban local, they have to keep silent until they confess that they are the palm oil farmers. Hence, a referred theory is taken from the authors who wrote that social structure is a rule that forms a norm, a role, and a status in a social group (In Assa, Puihli, Macap, Rumbiak, \& Mantiri, 2014). Social structure has several elements: firstly, the reciprocal relation of a community with the others. Secondly, the eternal pattern of participant behavior in a social system that pertains to others. Thirdly, the institutional norms or base knowledge that is structured and underlined the acts in a social system (Susilo in Kusmanto \& Elizabeth, 2018).

The expansion of palm oil plantation is seen as a way to decrease poverty and creates economic chances. Thus, an area is also necessary to be provided to preserve the Arfak locals and helps them continue their life. The palm oil plantation guarantees an increased life of the Arfak locals. Furthermore, it also encourages infrastructure development and creates jobs as well as increases the local income. The local people mention that palm oil is the optimum choice that can support their finance. Nonetheless, the major barrier for the effective community engagement is the dependence of indigenous people as subsistence farmers on the forest as well as their unfamiliarity with palm as a commercial plant.

The land is frequently in the conflict in Papua. Therefore, the government map out the communal right on the special autonomy regulation number 21 of 2001, and the government as the nation organizer should guarantee the achievement of customary rights. The palm oil plantation development resulted in deforestation and give a negative impact on the environment, such as bad water production and erosion. Then, reducing the environmental destruction and creating a better condition that is aimed for the involvement of local people productively become a main challenge for the planted investigation.

\section{Palm oil Effects}

By 11, 07 person/square kilometers of the population density in Warmare district and 41, 62 people/square kilometers in Prafi district, most probably shifting cultivation is still applied in both districts. Along with the growth of Manokwari regency, the area conversion is continuing to exist for palm area plantation and the plasma farmer housing has given a constriction for the area of shifting cultivation of Arfak local. Arfak farmers have witnessed a switching to the agriculture settled system, and yet there is no alteration for the farming practice. They keep using the subsistence way.

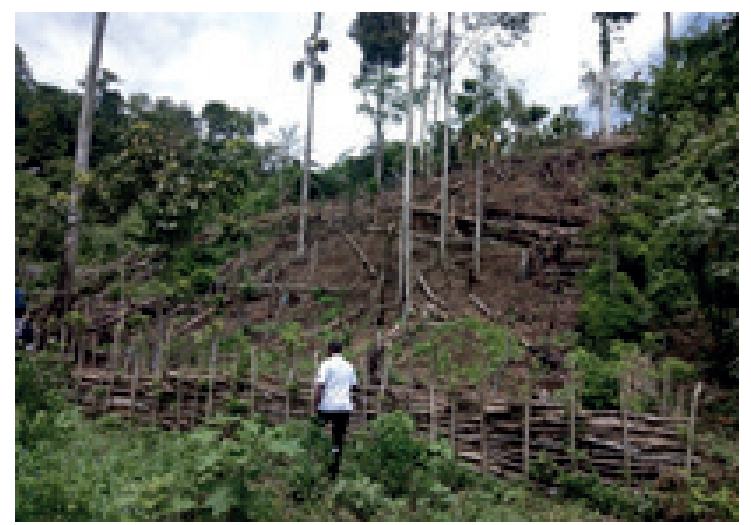

Figure 3 The planted area of Arfak farmer

Figure 3 draws the agriculture system conducted at the Arfak local in the research location. The system does not look like how their ancestors did. On this agriculture settled, farming is the only workaround palm oil plantation, yet they are also still plasma farmers. Based on the data of informant, (Mr. Mandacan Dorteus) states that:

\footnotetext{
"The big local of Arfak do the traditional cultivation. They aim only to fulfill their need of food. They do not know or use the modern technology such as contractor or the modern agriculture machines. They use only a machete, a dibble, and an axe. Simply, Arfak local and other Papua found their inspiration from the forest. Forest as food provider made the locals look like they really suspend their life on the forest and they keep holds their
}

The farm settled practice does not again need the handled of clan or family name in the tradition of shifting cultivation. An informant (Mr. Ullo Luther) informed that:

"...we make a farm around palm oil area. The farm is not large. So, when we open and handle that area, we do not need helps from many people to clean it, because we alone as a family can clean it and make a farm...not like before, our parents open a farm in the forest and need many people (our big family) to clean.... Now each family handle their own farm including the palm oil for about two hectares". The collective ritual is previously used for the area maintenance. Now, 
it has been changed by the personal activity with narrow meaning.

\section{Resettlement Program}

One purpose of the resettlement program is a technology transition. The association of other locals encourages the social culture practice of Arfak local to adapt to the alteration of the agricultural practice system efficiently. Culture practice may occur based on the behavior of the parties who count others' behavior about giving value for each party. Of course, this alteration occurs in a gradual way, not in a revolution. While the cultural social elements as a basic is not change (Sutarto, 2016)). The alteration is based on the substance pressing, not only cover the needs but also offer a new culture and main service (education, health and economy) (Chmieliński \& Chmielewska, 2015)

For the Arfak locals, cooperating in the core estate and being smallholders of palm oil has grown the consciousness that it is important to aid the development of a better living standard. As the plasma farmers, the Arfak locals should interact with all parties include the company parties, and it requires an openness to learn and take experience from other parties. Moreover, it literally gives an additional value economically. The integration process with other urbaner as fellow plasma farmers creates an interaction that gives several disadvantages. It can be seen from the possibility that the urban parties work in the farming area with consequences, which is they will feel insecure. On the other hand, the palm oil area is rent at a certain time. Thus, working as plasma farmers and being a part of a company becomes habitual. Then, Arfak local assumes that a shifting cultivation practice is not necessary. They can stay at home and get money every month. The Arfak local in the research location is less motivated to improve themselves up. It is because they only have a passion to be the same with the non-Papua farmers but they do nothing. Based on the ecology and social culture of Arfak local farmers, the social structure and human capital are the strategies used to upgrade their economy level. If the insight and knowledge of local farmers are not sharpened by coaching and assisting, then the social structure approach will not work in dealing with local problems. Many recent innovations technology has been rejected by the Arfak farmers because they do not suit their knowledge and technology. Working without technology for Arfak local is not aimed at having conservation, but the technology system is the top-down that is not suit their socio-economy and ecology circumstances. The change of farm practice from shifting cultivation to monoculture settled-farm has caused a culture shock for the Arfak local farmer. Therefore, the Arfak farmers think to get back to their shifting cultivation since it gives them cash. Subsistence culture applies the practices of taking and selling without any action. In addition, the culture has caused the communal values and togetherness to wash away from the farming practice; it only focuses on the individualistic practices that only concern on their own palm oil farm. Larson \& Rogers (in Muchammad \& Bagus, 1945) mentioned that alteration is a sustainable process in a certain time and relates to the using of technology. The social change usually occurs in a community or ethnic group which influence the social system, tradition, attitude, and behaviour pattern of other groups. The handling system of settled-farming is also applied to the pattern and the technique that similar to subsistence. This way may be identified as the food storage strategy that used as a supply for all year around. The limitation of knowledge and skill, as well as the lack of assistance, encouraged the Arfak farmer to cope with the problems intensively like a non-Papua farmer/ national transmigration did. A reluctance to adopt a better agriculture system is disturbed by limited input (the capital, the labor, and the area): "sooner or later, the farming system of Papua indigenous will undergo an alteration. The five factors of the alliteration are the pressure from people around, the decrease in labor because they focus on the new pattern, the growing of agricultural technology and the existence of a new pattern, the recycle distraction of nutrients (the ecology and the field ecosystem), field ethnology that is not functioned as behaviour guidelines in handling the farm of the Papua community (Sagrim, n.d.).

\section{Conclusions}

To sum up, the first is the shifting cultivation in Indisey and Somi villages have similar stages. It is because they have the same ancestor from Arfak mountain. The shifting cultivation in both villages covers the dark color of soil or red soil. The soil is fertile signed by trees known as Bembuk and Ciskua. Labour derives mainly from their own family with the productive age of 33 on the average and the minimum age of 20 years 
old. Men do a hard level job such as cutting down the tree, making a fence, digging and doing the hoe; while women do simple jobs that need patience and neatness such as slashing, planting, fertilizing, harvesting, and marketing. Arfak traditional Policy is Igya ser hanjob. It is a local instrument that connects them to the cosmos directly. If there is any value that is ignored by the Arfak locals, then they will be isolated from the cosmos and the indigenous.

The socio economy situation in Indisey and Somi villages draws an attachment that builds a high integration. They are not reluctant to help each other by giving aids such as paying the fine if a clan is convicted of criminal activity, the dowry payment tradition, the violation of social norms. Having fulfilled their food needs and have no worries about life are two perspectives that become human capital barriers. They say that the limited of their knowledge and skill level make them need any suggestions from others. The local conflicts emerged due to the culture shock of resettlement and the palm oil expansion as two programs conducted by the government where the farmers have difficulties in learning them.

\section{References}

Ainembabazi, J. H., \& Mugisha, J. (2014). The Role of Farming Experience on the Adoption of Agricultural Technologies: Evidence from Smallholder Farmers in Uganda. Journal of Development Studies, Vol. 50, pp. 666-679. https://doi.org/10. 1080/00220388.2013.874556

Assa, V. R., Puihli, I. S., Macap, A. R., Rumbiak, A. R., \& Mantiri, G. J. M. (2014). Sistem Politik Tradisional Etnis Find di Distrik Senggi Kabupaten Keerom : Struktur Sosial dan Kepemimpinan Etnis Find. Retrieved from http://kebudayaan. kemdikbud.go.id/bpnbjayapura/wpcontent/uploads/sites/17/2015/11/ SENGGI.pdf

Bass Stephen and Elanie Morrison. (1994). Shifting Cultivation in Thailand, Laos and Vietnam: Regional Overview and Policy Recommendations. IIED Forestry and Land Use Series, 2, 1-48.

Cavenett. (2013). Shifting Cultivation and Food Security. In C. Erni (Ed.), Journal of Chemical Information and Modeling (Vol. 53). https://doi.org/10.1017/ CBO9781107415324.004

Chmieliński, P., \& Chmielewska, B. (2015).
Social changes in rural areas: Incomes and expenditures of rural households. Ekonomika Poljoprivrede, 62(4), 907-920. https://doi.org/10.5937/ekopolj1504907c

Das, A. B., \& Sahoo, D. (2012). Farmers' educational level and agriculture productivity: a study of tribals of KBK districts of Odisha. International Journal of Education Economics and Development, 3(4), 363. https://doi.org/10.1504/ IJEED.2012.052312

Deda, A., \& Mofu, S. (2014). Masyarakat Hukum Adat Dan Hak Ulayat Di Provinsi Papua Barat Sebagai Orang Asli Papua Ditinjau Dari Sisi Adat Dan Budaya: Sebuah Kajian Etnografi Kekinian. Jurnal Administrasi Publik Unpar, 11(2), 11-22.

Hastanti, B. W., \& Yeny, I. (2009). Strategi Pengelolaan Cagar Alam Pegunungan Arfak Menurut Kearifan Lokal Masyarakat Arfak Di Manokwari Papua Barat. Sosial Ekonomi, 9(1), 19-36.

Howay, J. (2016, January). Corak Produksi Manusia Papua Dulu dan Kini. pp. 1-5.

Hujairin, M., Ismadi, A., \& Kustana, T. (2017). Revitalisasi Kearifan Lokal Suku Arfak di Papua Barat Dalam Rangka Mendukung Ketahanan Pangan Wilayah. Prodi Manajemen Pertahanan, 3(1), 53-77.

Ickowitz, A. (2004). Shifting Cultivation and Deforestation: questioning the dominant narrative in tropical Africa. (April).

Kafle Gandhiv. (2011). An overview on shifting cultivation with reference to Nepal. Scientific Research and Essays, 6(31), 6509-6514. https://doi.org/10.5897/ SRE11.1282

Kusmanto, T. Y., \& Elizabeth, M. Z. (2018). Struktur dan Sistem Sosial pada Aras Wacana dan Praksis. JSW: Jurnal Sosiologi Walisongo, 2(1), 39. https:// doi.org/10.21580/jsw.2018.2.1.2252

Muchammad, R., \& Bagus, C. S. A. P. (1945). Literasi Dampak Penggunaan Smartphone bagi Kehidupan Sosial di Desa Ngadirijo, Kabupaten Pacitan. Journal Comunication of Studies, 5(1), 15-30.

Obidzinski, K., Andriani, R., Komarudin, H., \& Andrianto, A. (2012). Environmental and social impacts of oil palm plantations and their implications for biofuel production in Indonesia. Ecology and Society, 17(1). https://doi.org/10.5751/ES-04775170125

Papua, W., \& Islands, A. (n.d.). Deforestation Over Time in the Land of Papua.

R.S. Tripathi and S.K. Barik. (2003). Shifting Cultivation. Shifting Cultivation in 
North East India, pp. 317-322. https:// doi.org/10.1007/978-94-024-11799_301397

Rahman, S. A., Rahman, M. F., \& Sunderland, T. (2012). Causes and consequences of shifting cultivation and its alternative in the hill tracts of eastern Bangladesh. Agroforestry Systems, Vol. 84, pp. 141155. https://doi.org/10.1007/s10457011-9422-3

S. Ali, M. S., Yunus, A., \& Salman, D. (2018). Rasionalitas Petani Dalam Merespons Perubahan Kelembagaan Penguasaan Lahan Dan Sistem Panen Pada Usahatani Padi. Jurnal Sosial Ekonomi Pertanian, 14(1), 1. https://doi.org/10.20956/jsep. v14i 1.3643

Sagrim, H. (n.d.). Menyelamatkan hutan adat papua sebagai suplai oksigen terbesar dunia. Retrieved from https://dokumen. tips/documents/forester-tabam-baik.html

Salosa, S. T., Awang, S. A., Suryanto, P., Purwanto, H., Yogyakarta, B., Kehutanan, F., \& Mada, U. G. (2015). Hutan Dalam Kehidupan Masyarakat Hatam Di Lingkungan Cagar Alam Pegunungan Arfak (Forest In Hatam Community Live On Arfak Mountains Natural Reserve Environment). Jurnal Manusia Dan Lingkungan, 21(3), 349-355. https://doi.org/10.22146/ jml. 18563

Singh, S., Purohit, J. K., \& Bhaduri, A. (2016). Shifting Cultivation in Odisha and Chhattisgarh: Rich Agro-Biodiverse Systems Under Risk. Jharkhand Journal of Development and Management Studies XISS, 14(2), 7023-7036.

Sodarak, H. (1999). Shifting cultivation practices by Hmong, Khamu and Lao ethnic categories in the Nam Nane watershed, Nane District, Luang Prabang (Unpublished master's thesis). 75.

Sugiyono. (2016). Metode Penelitian Kuatitatif, Kualitatif dan R\&D. Bandung: ALFABETA Bandung.
Surtantin, E., Sutjipta, N., \& Parining, N. (2018). Analisis Dinamika Kelompok pada Gapoktan Sekar Sari Desa Pangean Kecamatan Maduran Kabupaten Lamongan. Jurnal Agribisnis Dan Agrowisata (Journal of Agribusiness and Agritourism), 7(2), 266. https://doi.org/10.24843/jaa.2018. v07.i02.p10

Sutarto, D. (2016). Kearifan Budaya Lokal Dalam Pengutan Tradisi Malemang Di Tengah Masyarakat Modernisasi Di Sungai Keruh Musi Banyuasin Sumatera Selatan. Jurnal Dimensi, 5(3), 2-6. Retrieved from https://www.journal.unrika.ac.id/index. php/jurnaldms/article/view/54

Talaohu, M. (2013). Perladangan Berpindah: Antara Masalah Sosial dan Masalah Lingkungan. Jurnal Populis, 7(1), 59-63.

Watch, K. B. P. P. S. (2013). Sawit Kian Menggusur Hutan Papua - Sawit Watch. Retrieved from Sawith watch website: http://sawitwatch.or.id/

Wescott, S. (2017). An Office with a View: Examining the Barriers for Young People Entering into Farming Today. In The Future of Alternative Agriculture in the Upper Midwest: Key Questions, Opportunities and Constraints.

Wijaya, H. (2018). Ringkasan dan Ulasan Buku Analisis Data Penelitian Kualitatif (Prof. Burhan Bungin). (March).

Yuminarti, U. (2017). Kebijakan Transmigrasi Dalam Kerangka Otonomi Khusus Di Papua: Masalah Dan Harapan. Jurnal Kependudukan Indonesia, 12(1), 13. https://doi.org/10.14203/jki.v12i1.215

Yuminarti, U., Darwanto, D. H., Jamhari, J., \& Subejo, S. (2018). Studi Komparasi Praktik Perladangan Berpindah Dan Pertanian Menetap Untuk Mendukung Ketahanan Pangan Masyarakat (Studi Pada Usahatani Kentang di Kabupaten Pegunungan Arfak). Jurnal Ketahanan Nasional, 24(2), 215. https://doi.org/10.22146/jkn.35367 